\title{
Defining the commercial determinants of health: a systematic review
}

\author{
Cassandra de Lacy-Vawdon and Charles Livingstone ${ }^{*}$ (])
}

\begin{abstract}
Background: Despite increasing attention to the social determinants of health in recent decades, globally there is an unprecedented burden from non-communicable diseases (NCDs). Recently, the corporate and commercial conditions associated with these, commercial determinants of health $(\mathrm{CDOH})$, have also begun to receive attention. This research aims to articulate the $\mathrm{CDoH}$ as described in the literature, summarize substantive findings, and assess strengths and limitations of current literature.

Methods: Systematic review of formal (Medline, EMBASE, Scopus, Global Health) and grey literature (database, Google Advanced, targeted website, citation searching). Searching identified 125 texts for full-text review, with 33 included for final review. Data extracted were analyzed thematically.

Results: The dynamics constituting $\mathrm{CDoH}$ include broad facilitators such as globalization of trade, corporate structures, and regulatory systems, articulation of social and economic power, neoliberal and capitalist ideologies; additional elements include corporate activities such as marketing, corporate political activities, corporate social responsibility, extensive supply chains, harmful products and production, and issues of accessibility. These contribute significantly to worsened global health outcomes.

Conclusions: Literature describing effects of macro conditions and corporate activities on health could usefully utilize $\mathrm{CDoH}$ terminology. Facilitation via revised, consistent and operational definition of $\mathrm{CDoH}$ would assist. Social, political, commercial and economic structures and relations of $\mathrm{CDOH}$ are under-theorized. Systematic approaches to identifying, describing, and disrupting these are required to improve global health.
\end{abstract}

Keywords: Commercial determinants of health, Global health, Non-communicable diseases

\section{Background}

Recently, research addressing social determinants of health $(\mathrm{SDoH})$, following formative work by Marmot and colleagues [1], has focused on identifying, describing, and beginning to address underlying social causes of population ill-health. However, SDoH approaches have yet to achieve far-reaching population health improvements. Globally, an unprecedented burden from noncommunicable diseases (NCDs) has developed [2]. NCDs are amongst the most pressing contemporary challenges

\footnotetext{
* Correspondence: charles.livingstone@monash.edu

School of Public Health and Preventive Medicine, Monash University, Melbourne, Australia
}

(c) The Author(s). 2020 Open Access This article is licensed under a Creative Commons Attribution 4.0 International License, which permits use, sharing, adaptation, distribution and reproduction in any medium or format, as long as you give appropriate credit to the original author(s) and the source, provide a link to the Creative Commons licence, and indicate if changes were made. The images or other third party material in this article are included in the article's Creative Commons licence, unless indicated otherwise in a credit line to the material. If material is not included in the article's Creative Commons licence and your intended use is not permitted by statutory regulation or exceeds the permitted use, you will need to obtain permission directly from the copyright holder. To view a copy of this licence, visit http://creativecommons.org/licenses/by/4.0/ The Creative Commons Public Domain Dedication waiver (http://creativecommons.org/publicdomain/zero/1.0/) applies to the data made available in this article, unless otherwise stated in a credit line to the data. and middle-income countries alike, contributing to the double-burden of disease [3].

NCDs are often termed 'lifestyle diseases' given their origins in behaviors including diet, physical inactivity, alcohol use, and tobacco use $[4,5]$. However, these behaviors are increasingly recognized as socially constructed choices heavily influenced by commercial interests $[6,7]$. Some call NCDs 'industrial epidemics' [8-12] or 'profit-' or 'corporate-driven diseases' [12-17] given the prominent involvement of commercial interests, entities and products. Meanwhile, others describe commercial conditions that influence health as 'corporate' or 'commercial determinants of health' (CDoH). Some researchers have 
called for $\mathrm{CDoH}$ to be afforded the same priority for disease prevention and research priority as $\mathrm{SDoH}[5,9,18]$, although some may view $\mathrm{CDoH}$ as a subset of $\mathrm{SDoH}$.

Despite increasing references to $\mathrm{CDoH}$ in the literature, to date, no systematic synthesis of the $\mathrm{CDoH}$ literature base has been produced. This review seeks to address this and distil the current $\mathrm{CDoH}$ evidence base. This systematic review aims to:

1. Articulate how $\mathrm{CDoH}$, and the prevention or minimization of harm associated with these, have been described in the literature;

2. Summarize substantive findings from identified research; and,

3. Assess the strengths and limitations of identified literature.

The working $\mathrm{CDoH}$ definition guiding initial stages of this review was that proposed by Kickbusch, Allen and Franz: "strategies and approaches used by the private sector to promote products and choices that are detrimental to health" [19].

\section{Methods}

This review was conducted in accordance with the Preferred Reporting Items for Systematic Reviews and Meta-Analyses (PRISMA) statement [20]. No protocol has been registered or published elsewhere. Peerreviewed literature and/or grey literature providing a definition and/or description of the drivers or underlying causes, channels or mechanisms, and/or outcomes associated with $\mathrm{CDoH}$, were included.

Original studies, reviews, commentaries, editorials, discussion papers, books and book chapters, reports, web articles and resources from government and nongovernment organizations, and conceptual works were included, where they met inclusion criteria. Other works such as newspaper and online news articles, presentations or speeches, and social media posts were excluded. Data could be qualitative, quantitative, or mixedmethod.

Papers naming $\mathrm{CDoH}$ directly, and/or describing similar concepts such as 'corporate determinants' or corporations and associated practices as social determinants of disease, ill-health, or NCDs were included. Whilst there is an expanse of literature that could be categorized as $\mathrm{CDoH}$, including literature that does not name the $\mathrm{CDoH}$ or associated terms explicitly, this review sought a narrower framing to focus in literature self-identified as pertaining to $\mathrm{CDoH}$.

\section{Search strategy}

The search strategy was fivefold and developed with the assistance of two specialist librarians. First, Medline
(Ovid), EMBASE (Ovid), Scopus, and Global Health databases were searched. Second, grey literature databases, including Community Guides (CDC), National Institute for Health and Care Excellence, Centre for Reviews Dissemination (University of York), and Health Evidence (Canada) were searched. Third, further grey literature searching was conducted using Google Advanced Searches consistent with systematic grey literature searching approaches described elsewhere [21, 22]. Fourth, targeted grey literature searching of key organizations' websites, consistent with previous approaches, was conducted [21, 22]. Finally, backwards and forwards citation searches were completed. See 'Additional file 1 Search strategies' for complete search strategies.

An iterative approach and preliminary search testing indicated appropriate search terms. A keyword search was adopted to capture the relevant $\mathrm{CDoH}$ literature ((commercial OR corporate).mp AND (determinant*.mp) AND (health OR disease*).mp). Databases were searched 15 May 2018, and all results were exported, duplicates removed, and screened using EndNote X8 software. Grey literature searches were conducted in June 2018, with results screened online, and relevant full-texts imported to EndNote. Consistent with previous studies the first 100 results for web searches were screened [22]. Citation searches were initially conducted 17 August 2018 and updated 29 March 2019.

\section{Literature selection}

Titles and abstracts were screened for all search results. Where abstracts were not available, executive summaries and/or tables of contents were used. Literature was excluded where it: was not published in English; included data and/or findings relating to non-humans; presented modelling, clinical and/or laboratory findings without examining underlying determinants; or, presented descriptive findings from population-level disease or risk behavior surveillance and/or public health or health promotion interventions without examining underlying determinants. We included literature that provided a definition and/or description of $\mathrm{CDoH}$, either naming these directly, or describing these indirectly as underlying determinants of health and/or disease as described previously.

Following screening, full texts were retrieved, with literature excluded where full texts were unavailable. Full texts were independently reviewed by two reviewers, and tabulated by one reviewer. Discrepancies were resolved via consultation between reviewers. Literature failing to meet inclusion criteria was excluded. Data extracted included author(s), date, title, publisher/source, type of publication, type of evidence provided, underpinning theories and/or frameworks used to frame analysis, and $\mathrm{CDoH}$ terms used (see Table 1). 
Table 1 Literature characteristics. Characteristics of the included literature

\begin{tabular}{ll}
\hline Author (Year) & Title \\
\hline $\begin{array}{ll}\text { Buse \& Hawkes } \\
\text { (2015) [13] }\end{array}$ & $\begin{array}{l}\text { Health in the } \\
\text { Sustainable } \\
\text { Development Goals: } \\
\text { ready for a paradigm } \\
\text { shift? }\end{array}$ \\
& \\
& \\
& \\
Buse, Tanaka \& & $\begin{array}{l}\text { Healthy people and } \\
\text { Hawkes (2017) [16] } \\
\text { healthy profits? } \\
\text { Elaborating a } \\
\text { conceptual framework } \\
\text { for governing the } \\
\text { commercial } \\
\text { determinants of non- } \\
\text { communicable dis- } \\
\text { eases and identifying } \\
\text { options for reducing } \\
\text { risk exposure }\end{array}$
\end{tabular}

Globalization and Health (Journal article)

$\begin{aligned} & \text { Publisher (Document Type of evidence } \\ & \text { type) }\end{aligned}$

Globalization and

Health (Journal article)

Narrative and

descriptive review of evidence base for the health-related targets in the (then) proposed Sustainable Development Goals in relation to disease burden and feasibility of interventions to achieve targets.

Narrative and descriptive analysis of and related health governance literature.

risk exposure
Collins, Mikkelsen, \& Axelrod (2019) [23]

Franz \& Kickbusch (2018) [24]

Freudenberg \& Galea (2008) [6]

Freudenberg \& Galea (2007) [25]
Interact, engage or partner? Working with the private sector for the prevention and control of noncommunicable diseases

The Capital-NCD-

Nexus: The commercial determinants of health and global capital flows

The impact of corporate practices on health: Implications for health policy
Corporate Practices (In Macrosocial Determinants of Population Health)

Hastings (2015) [9]
Public health and the value of disobedience
Cardiovascular

Diagnosis and Therapy (Journal article)

Eurohealth (Journal article)

Journal of Public Health Policy (Journal article)

Narrative and

descriptive paper describing the role of the private sector in noncommunicable disease prevention and control

Narrative and descriptive article discussing the role of global capital flows for health and noncommunicable diseases

Narrative and descriptive case studies $(n=3)$ of trans fats, sports utility vehicles, and a painkiller to examine the role of corporate policies and practices in the production of health and disease, and suggest policy implications.

Springer (Book Chapter)

Narrative and descriptive literature review of corporate practices that harm health with proposed conceptual model focusing on six industries.

Public Health (Journal article)

Narrative and descriptive application conceptual framework

$\begin{array}{ll}\begin{array}{l}\text { Underpinning theory/ } \\ \text { framework used to } \\ \text { frame analysis }\end{array} & \begin{array}{l}\text { Commercial } \\ \text { Determinants of } \\ \text { Health term(s) used }\end{array} \\ \text { None } & \begin{array}{l}\text { Commercial } \\ \text { determinants of ill- } \\ \text { health; and 'Profit- } \\ \text { driven-diseases' and } \\ \text { their commercial } \\ \text { determinants }\end{array}\end{array}$

Uses an existing conceptual framework designed to classify the involvement of the commercial sector in global governance for health. The framework presents three models of interaction between public and private sectors: self-regulation by industry; regulation through partnership; and regulation of the private sector by the public sector.

None

NCD risk factors and their underlying social and commercial determinants

None

Commercial determinants of health

None

Corporations as a social determinant of health

Presents an original conceptual model of the influences of corporate practices on health. Boétie's work on
Uses Etienne de la determinants of NCDs; commercial eterminants of commercial determinants of illhealth
Corporations as a social determinant of health

Commercial determinants of ill 
Table 1 Literature characteristics. Characteristics of the included literature (Continued)

\begin{tabular}{|c|c|c|c|c|c|}
\hline Author (Year) & Title & $\begin{array}{l}\text { Publisher (Document } \\
\text { type) }\end{array}$ & Type of evidence & $\begin{array}{l}\text { Underpinning theory/ } \\
\text { framework used to } \\
\text { frame analysis }\end{array}$ & $\begin{array}{l}\text { Commercial } \\
\text { Determinants of } \\
\text { Health term(s) used }\end{array}$ \\
\hline & & & $\begin{array}{l}\text { of concepts from } \\
\text { historic philosophical } \\
\text { writings to modern } \\
\text { day public health } \\
\text { challenges, including } \\
\text { corporate marketing. }\end{array}$ & $\begin{array}{l}\text { 'Voluntary Servitude' to } \\
\text { explore power and } \\
\text { public health. }\end{array}$ & health \\
\hline Hastings (2012) [5] & $\begin{array}{l}\text { Why corporate power } \\
\text { is a public health } \\
\text { priority }\end{array}$ & BMJ (Journal article) & $\begin{array}{l}\text { Narrative and } \\
\text { descriptive discussion } \\
\text { of corporate power, } \\
\text { and especially } \\
\text { corporate marketing, } \\
\text { as a public health } \\
\text { priority. }\end{array}$ & None & $\begin{array}{l}\text { Commercial } \\
\text { determinants of ill- } \\
\text { health }\end{array}$ \\
\hline $\begin{array}{l}\text { International } \\
\text { Federation of Medical } \\
\text { Students' } \\
\text { Associations, Team of } \\
\text { Officials (2017) [26] }\end{array}$ & $\begin{array}{l}\text { IFMSA Policy Non- } \\
\text { Communicable } \\
\text { Diseases }\end{array}$ & $\begin{array}{l}\text { International } \\
\text { Federation of Medical } \\
\text { Students' Associations } \\
\text { (Policy statement) }\end{array}$ & $\begin{array}{l}\text { Policy statement } \\
\text { incorporating } \\
\text { discussion of literature } \\
\text { as rationale (evidence) } \\
\text { for position. }\end{array}$ & None & $\begin{array}{l}\text { Commercial } \\
\text { determinants of } \\
\text { health }\end{array}$ \\
\hline $\begin{array}{l}\text { Ireland et al. (2019) } \\
\text { [27] }\end{array}$ & $\begin{array}{l}\text { Commercial } \\
\text { determinants of health } \\
\text { and sport sponsorship }\end{array}$ & $\begin{array}{l}\text { Bulletin of the World } \\
\text { Health Organization } \\
\text { (Journal article) }\end{array}$ & $\begin{array}{l}\text { Narrative and } \\
\text { descriptive discussion } \\
\text { of sport sponsorship as } \\
\text { a commercial } \\
\text { determinant of health }\end{array}$ & None & $\begin{array}{l}\text { Commercial } \\
\text { determinants of } \\
\text { health }\end{array}$ \\
\hline $\begin{array}{l}\text { Kadandale, Marten, \& } \\
\text { Smith (2019) [28] }\end{array}$ & $\begin{array}{l}\text { The palm oil industry } \\
\text { and noncommunicable } \\
\text { diseases }\end{array}$ & $\begin{array}{l}\text { Bulletin of the World } \\
\text { Health Organization } \\
\text { (Journal article) }\end{array}$ & $\begin{array}{l}\text { Narrative and } \\
\text { descriptive paper using } \\
\text { the Kickbusch et al. } \\
\text { (2016) CDoH } \\
\text { framework to frame } \\
\text { analysis of the palm oil } \\
\text { industry }\end{array}$ & $\begin{array}{l}\text { Uses Kickbusch et al. } \\
\text { (2016) commercial } \\
\text { determinants of health } \\
\text { framework to frame } \\
\text { analysis }\end{array}$ & $\begin{array}{l}\text { Commercial } \\
\text { determinants of } \\
\text { health }\end{array}$ \\
\hline Kickbusch (2015) [14] & $\begin{array}{l}\text { Addressing the } \\
\text { commercial } \\
\text { determinants is critical } \\
\text { to emerging } \\
\text { economies }\end{array}$ & $\begin{array}{l}\text { Ciencia \& Saude } \\
\text { Coletiva (Journal } \\
\text { article) }\end{array}$ & $\begin{array}{l}\text { Narrative and } \\
\text { descriptive brief article } \\
\text { describing need for } \\
\text { emerging economies } \\
\text { to take the lead in } \\
\text { addressing the } \\
\text { commercial } \\
\text { determinants of health } \\
\text { due to the unequal } \\
\text { effect on these } \\
\text { societies. }\end{array}$ & None & $\begin{array}{l}\text { Commercial } \\
\text { determinants of } \\
\text { health }\end{array}$ \\
\hline Kickbusch (2013) [29] & $\begin{array}{l}\text { A Game Change in } \\
\text { Global Health: The Best } \\
\text { Is Yet to Come }\end{array}$ & $\begin{array}{l}\text { Public Health Reviews } \\
\text { (Journal article) }\end{array}$ & $\begin{array}{l}\text { Narrative and } \\
\text { descriptive article } \\
\text { discussing the need } \\
\text { for a better-equipped } \\
\text { (health) governance } \\
\text { system to improve } \\
\text { health, address com- } \\
\text { mercial determinants, } \\
\text { and reduce } \\
\text { inequalities. }\end{array}$ & None & $\begin{array}{l}\text { Commercial } \\
\text { determinants of } \\
\text { NCDs; and } \\
\text { commercial } \\
\text { determinants of } \\
\text { health }\end{array}$ \\
\hline Kickbusch (2012) [18] & $\begin{array}{l}\text { Addressing the } \\
\text { interface of the } \\
\text { political and } \\
\text { commercial } \\
\text { determinants of health }\end{array}$ & $\begin{array}{l}\text { Health Promotion } \\
\text { International (Journal } \\
\text { editorial) }\end{array}$ & $\begin{array}{l}\text { Narrative and } \\
\text { descriptive article } \\
\text { describing the need to } \\
\text { address the political } \\
\text { and commercial } \\
\text { determinants of health } \\
\text { in order to continue to } \\
\text { move the health } \\
\text { agenda forward. }\end{array}$ & None & $\begin{array}{l}\text { Commercial } \\
\text { determinants of } \\
\text { health }\end{array}$ \\
\hline $\begin{array}{l}\text { Kickbusch, Allen \& } \\
\text { Franz (2016) [19] }\end{array}$ & $\begin{array}{l}\text { The commercial } \\
\text { determinants of health }\end{array}$ & $\begin{array}{l}\text { The Lancet Global } \\
\text { Health (Journal article) }\end{array}$ & $\begin{array}{l}\text { Narrative and } \\
\text { descriptive article to }\end{array}$ & $\begin{array}{l}\text { Presents and describes } \\
\text { a framework depicting }\end{array}$ & $\begin{array}{l}\text { Commercial } \\
\text { determinants of }\end{array}$ \\
\hline
\end{tabular}


Table 1 Literature characteristics. Characteristics of the included literature (Continued)

\begin{tabular}{|c|c|c|c|c|c|}
\hline Author (Year) & Title & $\begin{array}{l}\text { Publisher (Document } \\
\text { type) }\end{array}$ & Type of evidence & $\begin{array}{l}\text { Underpinning theory/ } \\
\text { framework used to } \\
\text { frame analysis }\end{array}$ & $\begin{array}{l}\text { Commercial } \\
\text { Determinants of } \\
\text { Health term(s) used }\end{array}$ \\
\hline & & & $\begin{array}{l}\text { introduce a new } \\
\text { definition of the } \\
\text { commercial } \\
\text { determinants of health } \\
\text { and present an } \\
\text { associated framework. }\end{array}$ & $\begin{array}{l}\text { the dynamics that } \\
\text { constitute the } \\
\text { commercial } \\
\text { determinants of health. }\end{array}$ & health \\
\hline $\begin{array}{l}\text { Kickbusch \& Szabo } \\
\text { (2014) [30] }\end{array}$ & $\begin{array}{l}\text { A new governance } \\
\text { space for health }\end{array}$ & $\begin{array}{l}\text { Global Health Action } \\
\text { (Journal article) }\end{array}$ & $\begin{array}{l}\text { Narrative and } \\
\text { descriptive article } \\
\text { describing need for } \\
\text { global public goods } \\
\text { for health and a rules- } \\
\text { based and reliably fi- } \\
\text { nanced global public } \\
\text { health domain to pro- } \\
\text { mote global health. }\end{array}$ & None & $\begin{array}{l}\text { Commercial } \\
\text { determinants of } \\
\text { global health; and } \\
\text { commercial } \\
\text { determinants of } \\
\text { health }\end{array}$ \\
\hline Knai et al. (2018) [31] & $\begin{array}{l}\text { Systems Thinking as a } \\
\text { Framework for } \\
\text { Analyzing Commercial } \\
\text { Determinants of Health }\end{array}$ & $\begin{array}{l}\text { The Millbank Quarterly } \\
\text { (Journal article) }\end{array}$ & $\begin{array}{l}\text { Narrative and } \\
\text { descriptive drawing on } \\
\text { a systems thinking } \\
\text { framework to frame } \\
\text { discussion }\end{array}$ & $\begin{array}{l}\text { Uses Donella } \\
\text { Meadows's systems } \\
\text { thinking framework }\end{array}$ & $\begin{array}{l}\text { Commercial } \\
\text { determinants of } \\
\text { health; commercial } \\
\text { determinants of } \\
\text { NCDs }\end{array}$ \\
\hline $\begin{array}{l}\text { Kosinska \& Ostlin } \\
\text { (2016) [32] }\end{array}$ & $\begin{array}{l}\text { Building systematic } \\
\text { approaches to } \\
\text { intersectoral action in } \\
\text { the WHO European } \\
\text { Region }\end{array}$ & $\begin{array}{l}\text { Public Health } \\
\text { Panorama (Magazine } \\
\text { editorial) }\end{array}$ & $\begin{array}{l}\text { Narrative and } \\
\text { descriptive overview of } \\
\text { the magazine issue } \\
\text { and the commercial } \\
\text { determinants of health, } \\
\text { with reference to the } \\
\text { Sustainable } \\
\text { Development Goals } \\
\text { and the Health } 2020 \\
\text { agenda. }\end{array}$ & None & $\begin{array}{l}\text { Commercial } \\
\text { determinants of } \\
\text { health }\end{array}$ \\
\hline $\begin{array}{l}\text { Madureira Lima \& } \\
\text { Galea (2018) [33] }\end{array}$ & $\begin{array}{l}\text { Corporate practices } \\
\text { and health: a } \\
\text { framework and } \\
\text { mechanisms }\end{array}$ & $\begin{array}{l}\text { Globalization and } \\
\text { Health (Journal article) }\end{array}$ & $\begin{array}{l}\text { Narrative and } \\
\text { descriptive article to } \\
\text { introduce a framework } \\
\text { for mapping corporate } \\
\text { activity. }\end{array}$ & $\begin{array}{l}\text { Uses Steven Lukes's } \\
\text { three-dimensional view } \\
\text { of power to study the } \\
\text { practices deployed by } \\
\text { commercial interests } \\
\text { to foster consumption. } \\
\text { Presents a framework } \\
\text { to study corporations } \\
\text { and commercial inter- } \\
\text { ests as a distal, struc- } \\
\text { tural, societal factor } \\
\text { that causes disease } \\
\text { and injury. }\end{array}$ & $\begin{array}{l}\text { Deaths worldwide } \\
\text {... attributable to } \\
\text { behavioral risk } \\
\text { factors that, at their } \\
\text { core, have the } \\
\text { consumption of } \\
\text { unhealthful } \\
\text { products and } \\
\text { exposures } \\
\text { produced by profit } \\
\text { driven commercial } \\
\text { entities; and } \\
\text { commercial } \\
\text { interests as distal, } \\
\text { structural, societal } \\
\text { factors that cause } \\
\text { disease and injury }\end{array}$ \\
\hline $\begin{array}{l}\text { McKee \& Stuckler } \\
\text { (2018) [34] }\end{array}$ & $\begin{array}{l}\text { Revisiting the } \\
\text { Corporate and } \\
\text { Commercial } \\
\text { Determinants of Health }\end{array}$ & $\begin{array}{l}\text { American Journal of } \\
\text { Public Health (Journal } \\
\text { article) }\end{array}$ & $\begin{array}{l}\text { Narrative and } \\
\text { descriptive article } \\
\text { outlining the } \\
\text { emergence of the } \\
\text { commercial } \\
\text { determinants of health, } \\
\text { how corporations } \\
\text { influence health, and } \\
\text { how public health } \\
\text { professionals can } \\
\text { respond to this power. }\end{array}$ & None & $\begin{array}{l}\text { Corporate and } \\
\text { commercial } \\
\text { determinants of } \\
\text { health }\end{array}$ \\
\hline Millar (2013) [15] & $\begin{array}{l}\text { The corporate } \\
\text { determinants of health: } \\
\text { How big business } \\
\text { affects our health, and } \\
\text { the need for }\end{array}$ & $\begin{array}{l}\text { Canadian Journal of } \\
\text { Public Health (Journal } \\
\text { article) }\end{array}$ & $\begin{array}{l}\text { Narrative and } \\
\text { descriptive } \\
\text { commentary } \\
\text { describing the effect } \\
\text { corporations have on }\end{array}$ & None & $\begin{array}{l}\text { Corporate } \\
\text { determinants of } \\
\text { health }\end{array}$ \\
\hline
\end{tabular}


Table 1 Literature characteristics. Characteristics of the included literature (Continued)

\begin{tabular}{|c|c|c|c|c|c|}
\hline Author (Year) & Title & $\begin{array}{l}\text { Publisher (Document } \\
\text { type) }\end{array}$ & Type of evidence & $\begin{array}{l}\text { Underpinning theory/ } \\
\text { framework used to } \\
\text { frame analysis }\end{array}$ & $\begin{array}{l}\text { Commercial } \\
\text { Determinants of } \\
\text { Health term(s) used }\end{array}$ \\
\hline & government action! & & $\begin{array}{l}\text { health in Canada and } \\
\text { the government action } \\
\text { needed to protect } \\
\text { consumers and reduce } \\
\text { harm. }\end{array}$ & & \\
\hline $\begin{array}{l}\text { Public Health } \\
\text { Association of } \\
\text { Australia (2018) [35] }\end{array}$ & $\begin{array}{l}\text { What are the } \\
\text { determinants of } \\
\text { health? }\end{array}$ & $\begin{array}{l}\text { Public Health } \\
\text { Association of Australia } \\
\text { (Web article) }\end{array}$ & $\begin{array}{l}\text { Narrative and } \\
\text { descriptive document } \\
\text { describing the } \\
\text { determinants of health, } \\
\text { including the social, } \\
\text { ecological, political, } \\
\text { commercial, and } \\
\text { cultural determinants } \\
\text { with reference to } \\
\text { relevant literature. }\end{array}$ & None & $\begin{array}{l}\text { Commercial } \\
\text { determinants of } \\
\text { health }\end{array}$ \\
\hline $\begin{array}{l}\text { Smith, Buse \& } \\
\text { Gordon (2016) [36] }\end{array}$ & $\begin{array}{l}\text { Civil society: the } \\
\text { catalyst for ensuring } \\
\text { health in the age of } \\
\text { sustainable } \\
\text { development }\end{array}$ & $\begin{array}{l}\text { Globalization and } \\
\text { Health (Journal article) }\end{array}$ & $\begin{array}{l}\text { Narrative and } \\
\text { descriptive article } \\
\text { using illustrative } \\
\text { examples to discuss } \\
\text { how civil society can } \\
\text { contribute to global } \\
\text { health. }\end{array}$ & None & $\begin{array}{l}\text { Commercial } \\
\text { determinants of } \\
\text { health }\end{array}$ \\
\hline $\begin{array}{l}\text { Smith, Dorfman, } \\
\text { Freudenberg, } \\
\text { Hawkins, Hilton, } \\
\text { Razum \& Weishaar } \\
\text { (2016) [37] }\end{array}$ & $\begin{array}{l}\text { Tobacco, Alcohol, and } \\
\text { processed Food } \\
\text { industries - Why Do } \\
\text { public Health } \\
\text { practitioners View } \\
\text { Them So Differently? }\end{array}$ & $\begin{array}{l}\text { Frontiers in Public } \\
\text { Health (Journal article) }\end{array}$ & $\begin{array}{l}\text { Narrative and } \\
\text { descriptive opinion } \\
\text { piece on how public } \\
\text { health should engage } \\
\text { with commercial } \\
\text { interests in tackling the } \\
\text { NCD epidemic. }\end{array}$ & None & $\begin{array}{l}\text { Social determinants } \\
\text { of NCDs }\end{array}$ \\
\hline $\begin{array}{l}\text { Sula-Raxhimi, } \\
\text { Butzbach, \& } \\
\text { Brousselle, (2019) [38] }\end{array}$ & $\begin{array}{l}\text { Planetary health: } \\
\text { countering commercial } \\
\text { and corporate power }\end{array}$ & $\begin{array}{l}\text { The Lancet Planetary } \\
\text { Health (Journal article) }\end{array}$ & $\begin{array}{l}\text { Narrative and } \\
\text { descriptive and } \\
\text { presents a framework } \\
\text { for countering the } \\
\text { effects of corporate } \\
\text { power and commercial } \\
\text { determinants of health }\end{array}$ & $\begin{array}{l}\text { Presents a framework } \\
\text { for countering the } \\
\text { effects of corporate } \\
\text { power and commercial } \\
\text { determinants of health, } \\
\text { inspired by ecological } \\
\text { determinants of health } \\
\text { and commercial } \\
\text { determinants of health } \\
\text { frameworks }\end{array}$ & $\begin{array}{l}\text { Commercial } \\
\text { determinants of } \\
\text { health }\end{array}$ \\
\hline Thorn (2018) [39] & $\begin{array}{l}\text { Addressing power and } \\
\text { politics through action } \\
\text { on the commercial } \\
\text { determinants of health }\end{array}$ & $\begin{array}{l}\text { Health Promotion } \\
\text { Journal of Australia } \\
\text { (Journal article) }\end{array}$ & $\begin{array}{l}\text { Narrative and } \\
\text { descriptive opinion } \\
\text { piece on power and } \\
\text { politics as relevant to } \\
\text { the commercial } \\
\text { determinants of health }\end{array}$ & None & $\begin{array}{l}\text { Commercial } \\
\text { determinants of } \\
\text { health }\end{array}$ \\
\hline Thurley (2017) [40] & $\begin{array}{l}\text { Explaining the links } \\
\text { between Commercial } \\
\text { Determinants of Health } \\
\text { and Chronic Diseases }\end{array}$ & $\begin{array}{l}\text { European Public } \\
\text { Health Alliance (Web } \\
\text { editorial) }\end{array}$ & $\begin{array}{l}\text { Narrative and } \\
\text { descriptive editorial } \\
\text { introducing and } \\
\text { contextualizing the } \\
\text { commercial } \\
\text { determinants of health } \\
\text { and promoting the } \\
\text { European Public } \\
\text { Health Alliance } 2017 \\
\text { Annual Conference. }\end{array}$ & None & $\begin{array}{l}\text { Commercial } \\
\text { determinants of } \\
\text { health }\end{array}$ \\
\hline $\begin{array}{l}\text { United Nations } \\
\text { Department of } \\
\text { Economic and Social } \\
\text { Affairs, and United } \\
\text { Nations Industrial } \\
\text { Development } \\
\text { Organization (2016) }\end{array}$ & $\begin{array}{l}\text { Report of the expert } \\
\text { meeting in preparation } \\
\text { for HLPF } 2017 \text { on } \\
\text { readying institutions } \\
\text { and policies for } \\
\text { integrated approaches } \\
\text { to implementation of }\end{array}$ & $\begin{array}{l}\text { United Nations } \\
\text { Department of } \\
\text { Economic and Social } \\
\text { Affairs, and United } \\
\text { Nations Industrial } \\
\text { Development } \\
\text { Organization (Meeting }\end{array}$ & $\begin{array}{l}\text { Descriptive report } \\
\text { highlighting the issues } \\
\text { raised during the } \\
\text { meeting attended by } \\
\text { representatives from } \\
\text { UN Member States, } \\
\text { international }\end{array}$ & None & $\begin{array}{l}\text { Corporate } \\
\text { determinants of } \\
\text { health }\end{array}$ \\
\hline
\end{tabular}


Table 1 Literature characteristics. Characteristics of the included literature (Continued)

\begin{tabular}{|c|c|c|c|c|c|}
\hline Author (Year) & Title & $\begin{array}{l}\text { Publisher (Document } \\
\text { type) }\end{array}$ & Type of evidence & $\begin{array}{l}\text { Underpinning theory/ } \\
\text { framework used to } \\
\text { frame analysis }\end{array}$ & $\begin{array}{l}\text { Commercial } \\
\text { Determinants of } \\
\text { Health term(s) used }\end{array}$ \\
\hline [41] & the 2030 Agenda & report) & $\begin{array}{l}\text { organizations, } \\
\text { academia and major } \\
\text { groups and other } \\
\text { stakeholders, with a } \\
\text { focus on the } \\
\text { Sustainable } \\
\text { Development Goals. }\end{array}$ & & \\
\hline $\begin{array}{l}\text { West \& Marteau } \\
\text { (2013) [42] }\end{array}$ & $\begin{array}{l}\text { Commentary on } \\
\text { Casswell (2013): The } \\
\text { commercial } \\
\text { determinants of health }\end{array}$ & $\begin{array}{l}\text { Addiction (Journal } \\
\text { article) }\end{array}$ & $\begin{array}{l}\text { Narrative and } \\
\text { descriptive } \\
\text { commentary in } \\
\text { response to Casswell }{ }^{58} \\
\text { describing the } \\
\text { commercial } \\
\text { determinants of health } \\
\text { in relation to the } \\
\text { alcohol industry. }\end{array}$ & None & $\begin{array}{l}\text { Commercial } \\
\text { determinants of } \\
\text { health }\end{array}$ \\
\hline Wiist (2006) [43] & $\begin{array}{l}\text { Public health and the } \\
\text { anticorporate } \\
\text { movement: Rationale } \\
\text { and recommendations }\end{array}$ & $\begin{array}{l}\text { Government, Politics, } \\
\text { and Law (Journal } \\
\text { article) }\end{array}$ & $\begin{array}{l}\text { Narrative and } \\
\text { descriptive article } \\
\text { discussing the possible } \\
\text { links between the anti- } \\
\text { corporate movement } \\
\text { and public health in } \\
\text { order to improve } \\
\text { health. }\end{array}$ & None & $\begin{array}{l}\text { The corporate } \\
\text { entity as a social } \\
\text { structural } \\
\text { determinant of } \\
\text { disease }\end{array}$ \\
\hline $\begin{array}{l}\text { World Health } \\
\text { Organization (2017) } \\
\text { [44] }\end{array}$ & $\begin{array}{l}\text { 2. Convening to } \\
\text { overcome commercial } \\
\text { determinants of health } \\
\text { (In Report of the } \\
\text { Regional Director: The } \\
\text { work of WHO in the } \\
\text { Western Pacific Region } \\
1 \text { July 2016-30 June } \\
\text { 2017) }\end{array}$ & $\begin{array}{l}\text { World Health } \\
\text { Organization (Report } \\
\text { section) }\end{array}$ & $\begin{array}{l}\text { Narrative and } \\
\text { descriptive chapter } \\
\text { describing the effect of } \\
\text { the commercial } \\
\text { determinants of health } \\
\text { on diet and the need } \\
\text { to address these to } \\
\text { improve health } \\
\text { outcomes. }\end{array}$ & None & $\begin{array}{l}\text { Commercial } \\
\text { determinants of } \\
\text { health }\end{array}$ \\
\hline $\begin{array}{l}\text { World Health } \\
\text { Organization } \\
\text { Regional Office for } \\
\text { Europe (2016) [45] }\end{array}$ & $\begin{array}{l}\text { Good governance for } \\
\text { the health and well- } \\
\text { being of all children } \\
\text { and adolescents }\end{array}$ & $\begin{array}{l}\text { World Health } \\
\text { Organization Regional } \\
\text { Office for Europe } \\
\text { (Conference paper) }\end{array}$ & $\begin{array}{l}\text { Narrative and } \\
\text { descriptive thematic } \\
\text { paper describing the } \\
\text { need for governance } \\
\text { to promote health and } \\
\text { wellbeing in children } \\
\text { and adolescents. }\end{array}$ & None & $\begin{array}{l}\text { Commercial } \\
\text { determinants of } \\
\text { health }\end{array}$ \\
\hline
\end{tabular}

Source: Texts included for systematic review

\section{Quality assessment}

As $\mathrm{CDoH}$ represent an emerging research field, it was anticipated that literature would be primarily descriptive and conceptual rather than rich in original data and analyses. Applying risk of bias assessment tools (e.g., Cochrane Handbook for Systematic Reviews [46] or the Consolidated Criteria for Reporting Qualitative Research [47]) was therefore inappropriate. Instead, type and source of publication, type of evidence used, and any underpinning frameworks or theories were appraised. Broad comments on evidence quality are included.

\section{Synthesis of results}

Meta-analysis was not appropriate. Thematic analysis using an inductive approach to the generation of themes and sub-themes, framed by the research aims, was adopted. This process involved stages of coding and summarizing thematic material and presenting these to form a novel synthesis of the current literature.

\section{Results}

\section{Literature selection}

Database searching yielded 2719 results. After removing duplicates 1258 abstracts were screened and 64 texts were identified for full review. Grey literature searches yielded almost 22,000 results, of which 1369 were screened, with 15 included for full text review. Citation searching led to 310 screened texts, and 46 full text reviews. Thirty-two texts were included for final review (see Fig. 1). 


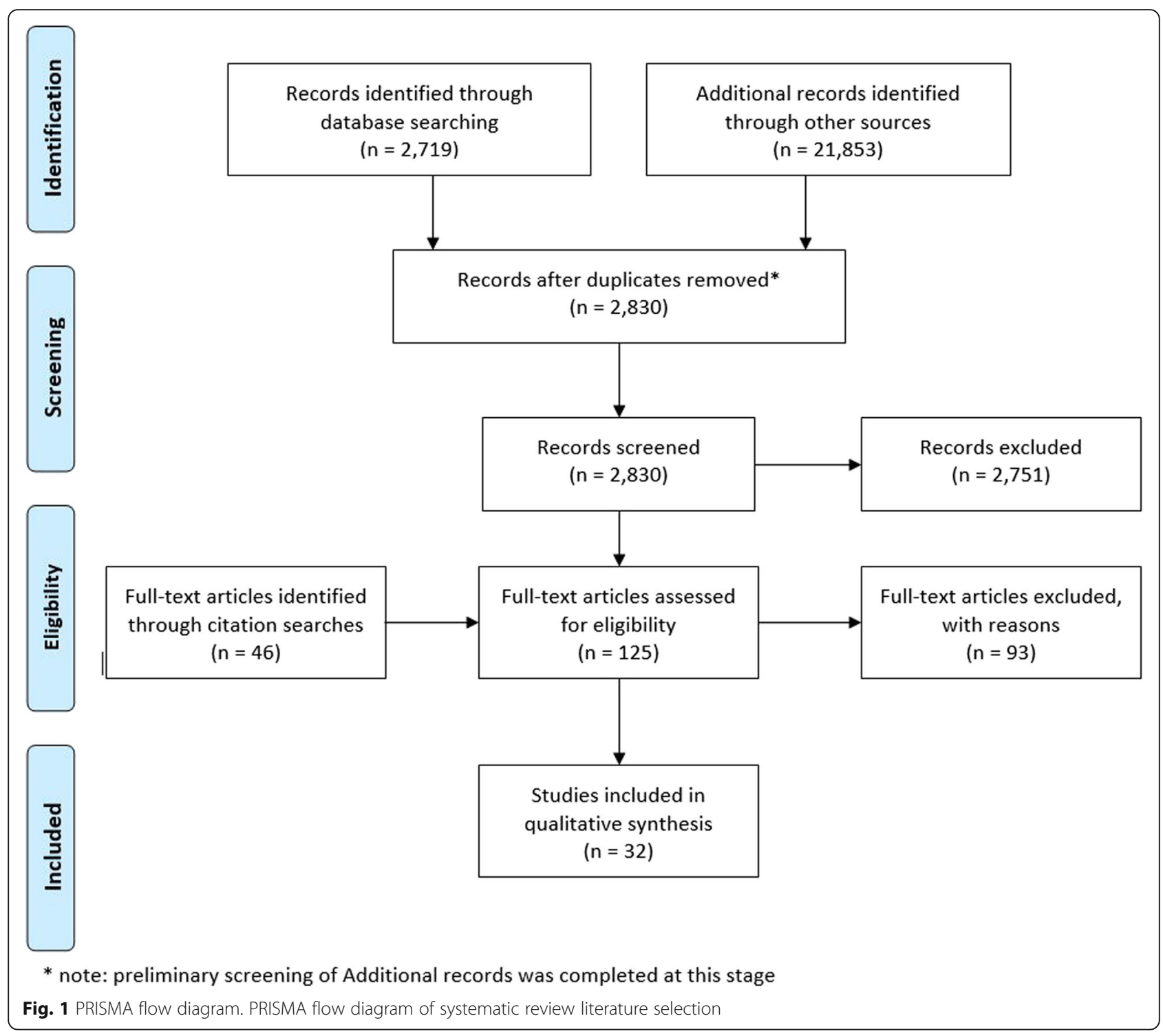

\section{Literature characteristics and quality assessment}

Texts analyzed were primarily journal articles $(n=24)$. Two organizational web articles, a book chapter, a conference paper, a magazine editorial, a United Nations (UN) meeting report, a World Health Organization (WHO) report, and an organizational policy statement were included (see Table 1). Literature was primarily descriptive and conceptual. Based on traditional measures of quality, most of the included literature would be appraised as low quality, as would the evidence base overall.

There was a lack of systematic analysis and original data in the included literature, with most including, at best, narrative reviews of relevant literature. Whilst a number of analyses used illustrative examples to describe $\mathrm{CDoH}$ (e.g., Smith, Buse, Gordon [36]) only two presented structured case studies $[6,28]$.
Eight texts framed analysis through theory and/or frameworks. Two included theoretical descriptions of power. Hastings [9] used de la Boétie's work on 'Voluntary Servitude', exploring power relations relevant to public health in modern society. Madureira Lima and Galea [33] used Lukes's three-dimensional view of power to study commercial practices that foster consumption, presenting an original framework to study corporate and commercial causes of disease and injury.

Kickbusch et al. [19] presented a specific $\mathrm{CDoH}$ framework. Kadandale et al. [28] used this to frame their analysis of the palm oil industry. Sula-Raxhimi et al. [38], drawing on this and an ecological determinants framework, presented a framework for countering corporate power and $\mathrm{CDoH}$, referencing planetary health. Knai et al. [31] described how Meadows's systems thinking framework may be used to understand $\mathrm{CDoH}$. Freudenberg and 
Galea [25] included a conceptual model of the influences of corporate practices on health. Buse et al. [16] used an existing framework to classify commercial sector involvement in global governance for health.

\section{Defining commercial determinants}

No widely accepted $\mathrm{CDoH}$ definition was apparent. Most $(n=19)$ texts provided no definition. Three prominent definitions were identified.

Most simply, $\mathrm{CDoH}$ were termed "factors that influence health which stem from the profit motive" by West and Marteau [42]. This definition was referenced in three other texts $[19,27,30]$. Kickbusch et al. [19] emphasized that this definition fails to distinguish between companies selling health-harming and health-promoting products. Kickbusch et al. [19] instead defined $\mathrm{CDoH}$ as "strategies and approaches used by the private sector to promote products and choices that are detrimental to health", emphasizing that this definition conceptually ties together both macro- (i.e., globalization, global risk society, and global consumer society) and micro- (i.e., individualization, choice and consumer health behavior) concepts, emphasizing these as 'dynamics'. This definition was used in six other texts [23, 24, 26, 28, 40,44].

Kosinska and Ostlin [32] provided a broader 'working definition' of $\mathrm{CDoH}$ that considered "a good or a service where there is an inherent tension between the commercial and the public health objective", including where the public health imperative is to reduce use or consumption and the commercial imperative is to increase this, or, conversely, where the public health objective is to increase accessibility and affordability and the commercial objective is to reduce this. The first two definitions describe $\mathrm{CDoH}$ as broad, systemic factors and dynamics that shape health. However, the third definition frames $\mathrm{CDoH}$ as arising from products and services specifically. This definition was also included in a WHO report on governance for children and adolescents' health and well-being [45].

\section{Macro-level conditions constituting $\mathrm{CDoH}$ Power}

Most commonly, $\mathrm{CDoH}$ were described as resulting from expressions of economic and political power wielded by large corporate entities, described as "powerful economic operators" $[16,19,30,35]$. Power imbalances were described both between corporations (large, for-profit, often trans-national entities) and governments with conflicting interests [30, 33, 34, 39, 43], and between corporations and individual citizens, driving behaviors that harm health $[6,33,39]$.

Corporate power was said to influence decision making, with corporations sometimes directly involved in public health policymaking [31]. Buse and Hawkes [13] described power as being used to maintain the status quo and deliberately keep 'difficult' topics off the agenda. Kickbusch [18] discussed transnational companies' power to influence political decision-making as largely underestimated. Meanwhile, others argued that $\mathrm{CDoH}$ are founded upon unchecked and unseen power exerted by corporations who frame dominant health narratives and agendas [23, 25, 34, 38]. This form of power was described as one of three proposed dimensions of power, alongside power to set agendas and make decisions, and power over conflict [33].

Overall, it was emphasized that powerful private sector interests commonly prevail over public health governance and accountability measures [5, 16, 38, 39]. The source of this power was reportedly changing patterns of global business and consumption, led by rising demand, increasing market coverage, and internationalization of trade and investment $[18,19]$.

\section{Other macro-level conditions constituting $\mathrm{CDoH}$}

Social constructs including ideology, neoliberalism and capitalism, globalization, trade agreements, corporate structures and rights, and regulation, were discussed as other macro-level conditions of $\mathrm{CDoH}$.

Kickbusch [18] asserts that

"It has become common practice to turn a health challenge into a fundamental debate about individual freedom and choice. Because health is at the intersection of values and ideology, between market forces and 'the state'."

Corporations reportedly favor personal responsibility for health over regulation [6, 27, 33, 34]. Hastings [5] suggested public health professionals need to drive a swing away from corporate capitalism towards economic systems that better promote public health. Others emphasized the role of neoliberal systems overall, and the importance of addressing these in the interests of improved health $[9,39]$.

$\mathrm{CDoH}$ were described as products of contemporary macroeconomics, facilitated by globalization and transnationalization of corporations. Many described the globalization of trade and investment, including increased activity within low and middle-income countries, as driving harm and challenging efforts to address $\mathrm{CDoH}$ effectively [16, 18, 19, 23, 24, 28, 29, 31, 40, 43, 44]. Notably, food and tobacco industries were cited as the "most internationalised businesses in the entire economy" [24].

Trade agreements and liberalization were described as contributing to worsened health outcomes [16, 24, 31, $34,36,41,43,44]$. The consequences of such agreements relate to occupational conditions, environmental conditions, health systems coverage, tax revenue lost via 
deregulated global finance systems, the affordability of pharmaceuticals, and national food systems and diets [24, 25, 33, 34, 41]. However, others emphasized that corporations could be more effectively used in prevention efforts, such as through corporate social responsibility (CSR) programs [15, 23, 43].

Overall, corporate structures and rights were critiqued as being, predominantly, at odds with public health due to profit maximization imperatives $[5,9,23-25,31,38$, 39]. West and Marteau [42] argue "The greatest challenge to improving health may lie in the tension between wealth- and health-creation". Wiist [43] emphasized that health-harming products and services are reflective of corporations' legal responsibilities to investors.

Corporate rights, including intellectual property rights, were described as presenting challenges to many interventions that could benefit public health $[16,33,34,43]$. Meanwhile, corporations being afforded similar rights as individuals, but with limited liability, was described as contributing to public health harms, and promoting unethical practice $[25,33,43]$.

Regulation of corporations contributing to $\mathrm{CDoH}$ was reportedly inadequate for preventing ongoing harm [14-16, 27, 31, 33, 39]. Self-regulation by industry was perceived as being the prominent model of regulation [16, 31, 33]. Corporations reportedly stave off public regulation via self-regulation [25, 33] and other methods [16, 25, 27, 30, 31, 33, 34, 37, 39, 43].

\section{Groups targeted by corporate activities}

Groups described as being targeted by corporate actions within $\mathrm{CDoH}$ systems included: individual consumers $[6$, $9,25,33]$, groups living in vulnerable circumstances, including children [6, 24-27, 31, 33, 45]; public health professionals and organizations [25,33]; researchers and research organizations $[6,25,33]$; philanthropic organizations [33]; not-for-profit organizations [33]; special interest groups and civil society [33]; the WHO and the UN more broadly $[16,33]$; and government representatives $[5,6,9,16,25,39]$. These groups were also, at times, described as promoting the interests of commerce and $\mathrm{CDoH}$ indirectly through their core activities. For instance, 'industry friendly' opinion leaders active within these organizations, philanthropic and/or sponsorship activities, and others, can shape research and policy agendas [33]. Concerns over managing these and other potential conflicts of interest were raised by several authors $[16,23,31,32]$.

Social, economic and commercial structures, relations and activities through which $\mathrm{CDoH}$ manifest

Core structures, relations, and activities through which $\mathrm{CDoH}$ manifest included marketing, corporate political activities (CPA) (such as lobbying, litigation, political donations, political relationship building, etc.), CSR, extensive and highly integrated supply chains, products and production detrimental to health, and the accessibility of such products.

Marketing and advertising of unhealthy commodities were widely described as harming health $[6,9,15,24$, $31,37]$ and enhancing the desirability and acceptability of unhealthy commodities $[19,23,26-28,35,40]$. Concerns over marketing to children were particularly prominent $[6,15,24,28,31,45]$. One article described corporate marketing as a pathogen [9]. Freudenberg and Galea [25] emphasized that corporations drive consumption by misrepresenting their products' health consequences and targeting vulnerable populations.

Corporations reportedly continue to spend significantly on marketing $[6,16]$, allowing unlimited access to consumers [44]. Some described marketing as being used to 'disguise corporations as friends' and to position industry as 'part of the solution' [5, 37]. Ireland et al. [27] described the "visibility and widespread appeal of sports" as frequently used to promote brands and products that harm health. Through media marketing agreements, corporations were said to gain influence over issues covered on media networks, and therefore over broader health and social narratives [33, 34].

Comprehensive regulation was described as the only strategy likely to effectively reduce the effects associated with marketing $[9,27,40]$.

CPA was described variously. Lobbying was regarded as a prominent barrier to healthy public policy, and often used to oppose policies beneficial to public health at the expense of corporate profits $[5,6,9,15,18,19$, $23,25,26,28,33-35,38,39,42]$. Lobbying directly from industry, and indirectly via other groups including think tanks and front groups was also discussed [33, 37].

Litigation, or threatening litigation, was another tactic described as being used against governments seeking to implement policies that might reduce industry profits $[6$, $16,25,33,42]$.

Arguments about infringements of personal choice and freedom of speech $[15,34,40]$ and obfuscation of scientific evidence through research community capture $[6,25,33,34]$ were cited as obstructing policy processes.

Other CPAs described included lucrative 'revolving door' arrangements shuffling individuals between government and commercial sectors, and political donations. Further, participation in government agencies, commissions, committees, and partnerships, pressures on international trade arrangements, and illegal activities were also discussed [5, 6, 16, 25, 27, 33, 34, 38, 39].

CSR is reportedly used to deflect attention from questionable practices, 'whitewash tarnished reputations' [19, $26,35]$, and enhance credibility and public perception $[5,9,16,19,23,27,28,33,37,40]$. These include 
voluntary activities that can undermine or delay official activities [33]. Millar [15] emphasized that while 'bad' corporations merely use CSR to offset the damage they do or raise their own profiles, 'good' corporations genuinely embrace CSR. Collins et al. [23] described publicprivate partnerships as opportunities for 'win-win' CSR scenarios through shared value creation. However, Kadandale et al. [28] highlighted that partner agencies risk becoming complicit in harmful practices.

Product formulation and production processes reportedly have significant impacts on health $[6,9,15,16,25$, $31,36]$. This was articulated as being attributable to corporations' increased investment in less healthy but more profitable products, added features that increase profits but harm health, resistance to inclusion of features that enhance health but add production costs, population targeting, and lax safety testing $[9,15,25]$. Others allege that product reformulation has often been used as a regulation avoidance tactic [33, 37]. Production processes also reportedly contribute significantly to diminished worker health and wellbeing $[25,28,34]$.

The extensive and highly integrated supply chains of modern companies were seen as amplifying influence globally $[9,19,23,24,26,28,31,35,40,43]$. This has reportedly affected consumption due to the abundance of unhealthy products, relative scarcity of healthy products, and low prices and high profit margins of unhealthy products compared to high costs and lower profit margins of healthy products $[24,25,34]$. This has also led to targeting vulnerable populations [5, 15, 25, 33].

To achieve elevated profits, corporations may externalize costs (environmental, health-related and otherwise) to avoid capturing the true aggregate 'cost' of their products $[5,6,9,15,25,33,34,43]$.

\section{Consequences of $\mathrm{CDoH}$}

Downstream consequences of $\mathrm{CDoH}$ were consistently described as premature death and disability associated with NCDs and chronic diseases including 'industrial epidemics' and 'profit driven' epidemics [5, 6, 9, 13-16, 24, 29-31, 33, 37, 40]. Cancers including lung cancer, obesity and overweight, cardiovascular diseases, chronic obstructive pulmonary disease, high cholesterol, diabetes, cirrhosis, and others were highlighted, as well as injuries. Buse and Hawkes [13] described vaccination and other pharmaceutical development and pricing as contributing to communicable disease outcomes.

Harms to population health were described as outcomes of 'toxic' environments. Kickbusch et al. [19] argued that "Health outcomes are determined by the influence of corporate activities on the social environment in which people live and work" emphasizing that environments shape individual lifestyles and choices that determine health outcomes. The International Federation of Medical
Students' Associations reiterated this [26] whilst Franz and Kickbusch [24] stressed "the argument that consumers can decide for themselves does not resonate" given the global consumer society context.

These environments were said to lead to malnutrition, stunting, overweight, obesity, and diabetes within the same populations [44]. Emerging global economies $[14,16,23,26]$, and the poor and "fragile middle" [14] countries were said to be worst affected.

Consequences for physical environments and planetary health associated production and trade included land clearing, lost biodiversity, air pollution, respiratory and cardiovascular diseases, and labor practices including child labor and inadequate maternity protections [28], and pollution, climate change and planetary health [38]. These articles also raised concerns for $\mathrm{CDoH}$ consequences for women in particular $[28,38]$.

\section{Proposals for harm minimization, and hierarchy of harmful industries}

$\mathrm{CDoH}$ literature most often referenced the food industry. However, the tobacco and alcohol industries were also frequently described. Pharmaceutical, automotive, firearms, mining and gambling industries were discussed to a lesser extent (see Table 2).

Tobacco industry discussions often referenced the WHO Framework Convention on Tobacco Control (FCTC), comparing it with other industries. Kickbusch [14] emphasized that while FCTC implementation has commenced, few governments have begun counteracting the influence of other unhealthy commodity industries.

Authors described a 'hierarchy' of harmful industries, where tobacco is portrayed as the 'worst' industry, whilst others were 'not as bad'. Kickbusch [18] and Ireland et al. [27] included examples from Fédération Internationale de Football Association (FIFA) who vetoed tobacco, yet regard alcohol as integral to the FIFA World Cup. This hierarchy was described as advantaging some industries in promoting their products, and discouraging government intervention. This was said of alcohol, food and gambling industries, compared to tobacco [42].

Some argued that practitioners should view tobacco, alcohol and processed food industries as equivalents, noting unfavorable outcomes associated with alcohol and obesity as "often in a magnitude comparable to that of tobacco" and health-related costs as similar and "perhaps highest for obesity, rather than for tobacco" [37].

Others highlighted the distinction between industries within WHO. Buse et al. [16] assert that

“WHO's institutional commitment to preventing and managing conflicts of interest with industry is unambiguous, but the scope of the challenge in 
Table 2 Included industries. Industries described in the literature reviewed

\begin{tabular}{|c|c|c|c|c|c|c|c|c|c|}
\hline Author (Year) & Food & Alcohol & Gambling & Tobacco & Pharmaceutical & Automotive & Firearm & Mining & Other \\
\hline Buse \& Hawkes (2015) [13] & $x$ & $x$ & & $x$ & & & & & \\
\hline Buse, Tanaka \& Hawkes (2017) [16] & $x$ & $x$ & & $x$ & & & & & \\
\hline Collins, Mikkelsen, \& Axelrod (2019) [23] & $x$ & $x$ & & $x$ & $x$ & & $x$ & & $x$ \\
\hline Franz \& Kickbusch (2018) [24] & $x$ & $x$ & & $x$ & & & & & \\
\hline Freudenberg \& Galea (2008) [6] & $x$ & $x$ & & $x$ & $x$ & $x$ & $x$ & & \\
\hline Freudenberg \& Galea (2007) [25] & $x$ & $x$ & & $x$ & $x$ & $x$ & $x$ & & \\
\hline Hastings (2015) [9] & $x$ & $x$ & & $x$ & $x$ & & & & \\
\hline Hastings (2012) [5] & $x$ & $x$ & & $x$ & $x$ & & & & \\
\hline $\begin{array}{l}\text { International Federation of Medical Students' } \\
\text { Associations, Team of Officials (2017) [26] }\end{array}$ & $x$ & $x$ & & $x$ & & & & & \\
\hline Ireland et al. (2019) [27] & $x$ & $x$ & $x$ & $x$ & & $x$ & & & $x$ \\
\hline Kadandale, Marten, \& Smith (2019) [28] & $x$ & $x$ & & $x$ & & & & & \\
\hline Kickbusch (2015) [14] & $x$ & $x$ & & $x$ & & & & & \\
\hline Kickbusch (2013) [29] & $x$ & $x$ & & $x$ & & & & & \\
\hline Kickbusch (2012) [18] & $x$ & $x$ & & $x$ & & & & $x$ & $x$ \\
\hline Kickbusch, Allen \& Franz (2016) [19] & $x$ & $x$ & & $x$ & & & & & \\
\hline Kickbusch \& Szabo (2014) [30] & $x$ & $x$ & & $x$ & & & & & \\
\hline Knai et al. (2018) [31] & $x$ & $x$ & $x$ & $x$ & & & & & \\
\hline Kosinska \& Ostlin (2016) [32] & $x$ & $x$ & & $x$ & $x$ & & & & \\
\hline Madureira Lima \& Galea (2018) [33] & $x$ & $x$ & & $x$ & $x$ & $x$ & & & \\
\hline McKee \& Stuckler (2018) [34] & $x$ & $x$ & & $x$ & $x$ & $x$ & $x$ & & \\
\hline Millar (2013) [15] & $x$ & $x$ & $x$ & $x$ & $x$ & & $x$ & $x$ & $x$ \\
\hline Public Health Association of Australia (2018) [35] & $x$ & $x$ & & $x$ & & & & & \\
\hline Smith, Buse \& Gordon (2016) [36] & $x$ & & & $x$ & $x$ & & & & \\
\hline $\begin{array}{l}\text { Smith, Dorfman, Freudenberg, Hawkins, Hilton, } \\
\text { Razum \& Weishaar (2016) [37] }\end{array}$ & $x$ & $x$ & & $x$ & & & & & \\
\hline Sula-Raxhimi, Butzbach, \& Brousselle, (2019) [38] & & & & $x$ & & & & & \\
\hline Thorn (2018) [39] & $x$ & $x$ & $x$ & $x$ & & & & & \\
\hline Thurley (2017) [40] & $x$ & $x$ & & $x$ & & & & & \\
\hline $\begin{array}{l}\text { United Nations Department of Economic and } \\
\text { Social Affairs, and United Nations Industrial } \\
\text { Development Organization (2016) [41] }\end{array}$ & $x$ & & & & & & & & \\
\hline West \& Marteau (2013) [42] & $x$ & $x$ & $x$ & $x$ & & $x$ & & $x$ & $x$ \\
\hline Wiist (2006) [43] & $x$ & $x$ & & $x$ & $x$ & $x$ & $x$ & & \\
\hline World Health Organization (2017) [44] & $x$ & & & & & & & & \\
\hline $\begin{array}{l}\text { World Health Organization Regional Office for } \\
\text { Europe (2016) [45] }\end{array}$ & $x$ & $x$ & & $x$ & $x$ & & & & $x$ \\
\hline
\end{tabular}

" $x$ " denotes where the industry has been mentioned at least once within the text

"other" industries included health technology, sporting goods and fitness, built environments, media and information technologies, healthcare [24], sport [26], textiles, energy, water [41], pornography, forestry, gaming, illicit drugs, helmet usage and others [15], oil [30], and health services [35]

Source: Texts included for systematic review

relation to commercial determinants of NCDs may be impossible to govern".

Thus, WHO's financial insecurity may be seen as possibly encouraging some forms of industry engagement, despite their stance on tobacco.
Authors appraised existing efforts to address $\mathrm{CDoH}$ as inadequate. Buse et al. [16] noted "While piecemeal efforts have been established, we argue that mechanisms to control the commercial determinants of NCDs are inadequate and efforts at remedial action too limited." Overall, the need for a new approach and/or paradigm 
shift to address $\mathrm{CDoH}$ harms was emphasized $[5,13,16$, $24,29,38,42]$.

The need for collaboration beyond single health issues $[6,18,31]$ and across sectors was discussed $[16,28,30$, 32, 36, 44, 45]. McKee and Stuckler [34] described the need to "address the power imbalance between global corporations, which are accountable only to their owners and shareholders, and governments, which are accountable to their citizens." Others reiterated these sentiments [24, 31, 38, 39]. Wiist [39] took this further, suggesting the need to restructure corporate entities, repeal corporate charters, remove corporate personhood rights, and restore liability to shareholders and officials. SulaRaxhimi et al. [38] suggested a need to find solutions outside the corporate wealth logic mechanisms.

Whilst much of the rights discussion focused on corporate legal and commercial rights, including trade, intellectual property, freedom of speech, and limited liability rights, some supported a reorientation towards human rights and social justice in order to achieve sustainable population health and wellbeing [13, 16, 28, 30, 36, 43].

\section{Discussion}

$\mathrm{CDoH}$ are described as underpinning many global health challenges. The $\mathrm{CDoH}$ literature ties together macro-level conditions such as economic and political systems, globalization, trade, power dynamics, corporate structures including rights and responsibilities, and regulatory and accountability approaches, with lower-level activities, structures and relations of corporations and related industry groups. However, much of this literature lacks specificity.

No $\mathrm{CDoH}$ definition has been consistently applied in the literature. Many authors fail to provide any definition, seemingly assuming some implicit understanding of $\mathrm{CDoH}$. The apparent discord between three definitions identified, whereby West and Marteau [42] emphasize health outcomes arising from the 'profit motive', Kickbusch et al. [19] emphasize the promotion of products and choices detrimental to health, and Kosinska and Ostlin [32] describe the tension between commercial and public health objectives specifically for goods and services, highlights a lack of precision within the $\mathrm{CDoH}$ literature. This may reflect the dynamic and reflexive nature of the relationships that constitute commercial influences on health.

Further, the $\mathrm{CDoH}$ term is not consistently applied. Some texts refer to corporations as elements of SDoH $[6,25]$ or disease [43], and to commercial interests as distal, structural, societal factors causing disease and injury [33]. Conceptually, these terms and associated discussions closely reflect $\mathrm{CDoH}$, and texts were accordingly included for review. However, other texts were excluded for failing to utilize $\mathrm{CDoH}$ language and/ or for failing to acknowledge macro-level conditions and/or associated structures, relations and activities as determinants of health and disease.

Many activities, such as marketing [8, 48, 49], CSR [8, $48]$, and, CPA [7, 49, 50] have been well-documented for their influence on behaviors and health. However, these have largely been studied in isolation, without considering the broader social, economic and political conditions facilitating them, and, at times, without regard for associated outcomes. Similarly, significant literature describes issues such as trade relations [51, 52], globalization [53, 54], health commercialization [55], conflicts between corporate and human rights $[55,56]$, and health-harming products [53, 57] without acknowledging these as determinants of health or $\mathrm{CDoH}$ specifically. This represents a lacuna in the evidence base.

Whilst $\mathrm{CDoH}$ outcomes are mostly described as harms, Millar [15] proposed that some corporate entities 'do real good' for the sake of doing good, whilst others highlighted the perception that some industries are not as harmful as others. McKee and Stuckler [34] indicated that corporations can be a 'force for good or bad', dependent on their activities and partnerships. These interpretations may suggest that $\mathrm{CDoH}$ could be positive or negative, with benefits and harms nuanced and circumstantial. We question whether harm and ill-health are defining consequences of $\mathrm{CDoH}$, or whether there could be scenarios, presently or in future, where commercial determinants could be consistent with public health interests and positively influence health. That is whether, as with $\mathrm{SDoH}, \mathrm{CDoH}$ occur along a gradient or nuanced spectrum, thereby influencing population health and wellbeing negatively and/or positively depending on the context. Whilst current literature focuses on negative outcomes it is possible that positive $\mathrm{CDoH}$ outcomes may eventuate with appropriate intervention and/or context. This warrants further exploration. In particular, this work could consider the $\mathrm{CDoH}$ from a systems perspective, recognize the influence of $\mathrm{CDoH}$ at various levels, and explore the structures and, most importantly, the reflexive relations that generate environments, conditions and behaviors that shape health and wellbeing. A new $\mathrm{CDoH}$ definition that considers these factors may assist in addressing the current lack of precision in the literature base, whilst also going some way to framing responsive and reflexive $\mathrm{CDoH}$ interventions in future.

This review documents the macro-level conditions, relations, structures and activities, and consequences constituting $\mathrm{CDoH}$ as described in the $\mathrm{CDoH}$ literature. That is, literature self-identified as describing $\mathrm{CDoH}$ and associated concepts. Given the nascent nature of the $\mathrm{CDoH}$ literature, this review provides a timely synthesis of the current state of understanding.

Some limitations apply to this review. The narrow searching frame may have meant that some literature pertaining to peripheral $\mathrm{CDoH}$ concepts may not have 
been captured in this review. Further, the working definition adopted for initial planning may present a potential limitation [19].

Reviewed literature was limited to that published in English only. As such, perspectives from high-income countries frame much of the literature. However, material reviewed also discusses implications for low- and middle-income countries, including understanding and concern for the flow of commercial influences into these countries $[5,14,16,19,23,26,28,34,38]$.

There are some inherent limitations to grey literature searching given the volume of results and the 'filter bubble', generated by search engines that tailor results to individual search histories and preferences. However, the inclusion of grey literature allowed for a more comprehensive review.

$\mathrm{CDoH}$ present an emerging, yet relatively underdeveloped, area of academic interest and concern. There is limited capacity to synthesize substantive findings, as these are not yet developed in the $\mathrm{CDoH}$-specific literature. So far, the literature has largely focused on describing, rather than addressing, harm. As such, approaches to preventing the harms associated with $\mathrm{CDoH}$ are largely hypothetical, with some important exclusions including tobacco control efforts. It is anticipated that the literature base will continue to expand over coming years, with future work beginning to explore this further in the context of $\mathrm{CDoH}$ specifically.

\section{Conclusions}

The $\mathrm{CDoH}$ field is of increasing social and public health relevance. Whilst the literature base is in its infancy, it has begun to illustrate the multiple elements constituting $\mathrm{CDoH}$, groups most affected, and resulting diminished population health outcomes. Overall, there is a need for greater specificity in the $\mathrm{CDoH}$ literature. As there is no widely accepted $\mathrm{CDoH}$ definition in use, evolution of this may be pertinent. Further, $\mathrm{CDoH}$ language should be more widely adopted to describe corporate influences on health and mechanisms reinforcing these globally, to better recognize these as significant contributors to global disease. In order to reduce NCDs and improve population wellbeing globally, systematic approaches to identifying, describing, and where necessary disrupting the complex conditions constituting $\mathrm{CDoH}$ are needed.

\section{Supplementary information}

Supplementary information accompanies this paper at https://doi.org/10. 1186/s12889-020-09126-1.

Additional file 1. Search strategies. Complete commercial determinants of health search strategies from database and grey literature searches.

\section{Abbreviations}

$\mathrm{CDoH}$ : Commercial determinants of health; CPA: Corporate political activity; CSR: Corporate social responsibility; FCTC: Framework Convention on
Tobacco Control; FIFA: Fédération Internationale de Football Association; NCD: Non-communicable disease(s); SDoH: Social determinants of health; UN: United Nations; WHO: World Health Organization

\section{Acknowledgements}

The authors would like to acknowledge and thank Cassandra Freeman and Kim Taylor, Monash University specialist subject librarians, for assistance in the development of search terms and strategy.

\section{Authors' contributions}

Both authors made substantial contributions to the conception and design of the work. CdV led data acquisition and analysis, with both authors responsible for interpretation. CdV drafted the work and $\mathrm{CL}$ provided substantial revisions. Both authors have approved the final version of this paper.

\section{Funding}

This research has not received any project specific funding.

$\mathrm{CdV}$ is a PhD student supported by an Australian Government Research

Training Program Scholarship, and a Monash Graduate Excellence

Scholarship provided by Monash University. Previously, CdV has also received project funding from the Susan McKinnon Foundation, the Victorian Responsible Gambling Foundation, the Victorian Department of Health and Human Services, municipal councils in Victoria, Australia, MOVE Muscle, Bone \& Joint Health, and Impact Investment Group. CdV has also worked for the Australian Gambling Research Centre at the Australian Institute of Family Studies, and received funding from the Australian Government Department of Social Services in this role.

$\mathrm{CL}$ has received funding from the Victorian Responsible Gambling Foundation, the (former) Victorian Gambling Research Panel, and the South Australian Independent Gambling Authority (the funds for which were derived from hypothecation of gambling tax revenue to research purposes), from the Australian and New Zealand School of Government and the Foundation for Alcohol Research and Education, and from non-government organizations for research into multiple aspects of EGM gambling, including regulatory reform, existing harm minimization practices, and technical characteristics of gambling forms. He has received travel and co-operation grants from the Turkish Green Crescent Society, Alberta Problem Gambling Research Institute, the Finnish Institute for Public Health, the Finnish Alcohol Research Foundation, the Ontario Problem Gambling Research Committee, and the Problem Gambling Foundation of New Zealand. He was a Chief Investigator on an Australian Research Council project researching mechanisms of influence on government by the tobacco, alcohol and gambling industries. He has undertaken consultancy research for local governments and nongovernment organizations in Australia and the UK seeking to restrict or reduce the concentration of poker machines and gambling impacts, and was a member of the Australian government's Ministerial Expert Advisory Group on Gambling in 2010-11, remuneration for which was paid to Monash University

\section{Availability of data and materials Not applicable.}

Ethics approval and consent to participate Not applicable.

\section{Consent for publication}

Not applicable.

\section{Competing interests}

The authors declare that they have no competing interests.

Received: 23 July 2019 Accepted: 16 June 2020

Published online: 29 June 2020

\section{References}

1. Marmot M. Social determinants of health inequalities. Lancet. 2005; 365(9464):1099-104

2. Allen L. Are we facing a noncommunicable disease pandemic? J Epidemiol Glob Health. 2017;7(1):5-9. 
3. Glasgow S, Schrecker T. The double burden of neoliberalism? Noncommunicable disease policies and the global political economy of risk. Health Place. 2016;39:204-11

4. Ackland M, Choi BCK, Puska P. Rethinking the terms non-communicable disease and chronic disease. J Epidemiol Community Health. 2003;57(11): 838-9.

5. Hastings G. Why corporate power is a public health priority. BMJ. 2012;345: e5124.

6. Freudenberg N, Galea S. The impact of corporate practices on health: implications for health policy. J Public Health Policy. 2008:29(1):86-104.

7. Freudenberg $\mathrm{N}$. The manufacture of lifestyle: the role of corporations in unhealthy living. J Public Health Policy. 2012;33(2):244-56.

8. Gilmore AB, Savell E, Collin J. Public health, corporations and the new responsibility Deal: promoting partnerships with vectors of disease? J Public Health. 2011;33(1):2-4

9. Hastings G. Public health and the value of disobedience. Ann Nutr Metab. 2015;129:66-7

10. Moodie R, Stuckler D, Monteiro C, Sheron N, Neal B, Thamarangsi T, et al. Profits and pandemics: prevention of harmful effects of tobacco, alcohol, and ultra-processed food and drink industries. Lancet. 2013;381(9867):670-9.

11. Herrick C. Alcohol, ideological schisms and a science of corporate behaviours on health. Crit Public Health. 2016;26(1):14-23.

12. Jahiel RI. Corporation-induced diseases, upstream epidemiologic surveillance, and urban health. J Urban Health. 2008;85(4):517-31.

13. Buse K, Hawkes S. Health in the sustainable development goals: ready for a paradigm shift? Glob Health. 2015;11:13.

14. Kickbusch I. Addressing the commercial determinants is critical to emerging economies. Cienc. 2015:20(4):968-9.

15. Millar JS. The corporate determinants of health: how big business affects our health, and the need for government action! Can J Public Health. 2013; 104(4):e327-9.

16. Buse K, Tanaka S, Hawkes S. Healthy people and healthy profits? Elaborating a conceptual framework for governing the commercial determinants of non-communicable diseases and identifying options for reducing risk exposure. Glob Health. 2017;13(1):34.

17. Collin J, Casswell S. Alcohol and the sustainable development goals. Lancet. 2016;387(10038):2582-3.

18. Kickbusch I. Addressing the interface of the political and commercial determinants of health. Health Promot Int. 2012;27(4):427-8.

19. Kickbusch I, Allen L, Franz C. The commercial determinants of health. Lancet Glob Health. 2016;4(12):e895-e6.

20. Moher D, Liberati A, Tetzlaff J, Altman DG. Preferred reporting items for systematic reviews and meta-analyses: the PRISMA statement. Int J Surg. 2009;8(5):336-41.

21. Briscoe $\mathrm{S}$. Web searching for systematic reviews: a case study of reporting standards in the UK health technology assessment programme. BMC Res Notes. 2015:8:153.

22. Godin K, Stapleton J, Kirkpatrick SI, Hanning RM, Leatherdale ST. Applying systematic review search methods to the grey literature: a case study examining guidelines for school-based breakfast programs in Canada. Syst Rev. 2015:4:138.

23. Collins T, Mikkelsen B, Axelrod S. Interact, engage or partner? Working with the private sector for the prevention and control of noncommunicable diseases. Cardiovasc Diagn Ther. 2019;9(2):158-64.

24. Franz C, Kickbusch I. The capital-NCD-nexus: the commercial determinants of health and global capital flows. Eurohealth (Lond). 2018;24(3):21-5.

25. Freudenberg N, Galea S. Corporate practices. In: Galea S, editor. Macrosocial determinants of population health. New York: Springer; 2007. p. 71-104.

26. International Federation of Medical Students' Associations. IFMSA Policy Non-Communicable Diseases. 2015. Available from: http://ifmsa.org/wpcontent/uploads/2015/05/2015AM_PS_Non-Communicable-Diseases.pdf. Accessed 29 Mar 2019

27. Ireland R, Bunn C, Reith G, Philpott M, Capewell S, Boyland E, et al. Commercial determinants of health: advertising of alcohol and unhealthy foods during sporting events. Bull World Health Organ. 97(4):290-5.

28. Kadandale S, Marten R, Smith R. The palm oil industry and noncommunicable diseases. Bull World Health Organ. 2019;97(2):118-28.

29. Kickbusch I. A game change in global health: The best is yet to come. Public Health Rev. 2013;35(1):1-20

30. Kickbusch I, Szabo MMC. A new governance space for health. Glob Health Action. 2014;7. https://doi.org/10.3402/gha.v7.23507.
31. Knai C, Petticrew M, Mays N, Capewell S, Cassidy R, Cummins S, et al. Systems thinking as a framework for analyzing commercial determinants of health. Milbank Q. 2018;96(3):472-98.

32. Kosinska M, Ostlin P. Building systematic approaches to intersectoral action in the WHO European region. Public Health Panorama. 2016;2(2):124-9.

33. Madureira Lima J, Galea S. Corporate practices and health: A framework and mechanisms. Global Health. 2018;14(1):21-32.

34. Mckee M, Stuckler D. Revisiting the corporate and commercial determinants of health. Am J Public Health. 2018;108(9):1167-70.

35. Public Health Association of Australia. What are the Determinants of Health? Australian Capital Territory: Public Health Association of Australia; 2018. Available from: https://www.phaa.net.au/documents/item/2756. Published May, 2018. Accessed 29 Mar 2019.

36. Smith J, Buse K, Gordon C. Civil society: the catalyst for ensuring health in the age of sustainable development. Global Health. 2016;12(1):40-5.

37. Smith K, Dorfman L, Freudenberg N, Hawkins B, Hilton S, Razum O, et al. Tobacco, alcohol, and processed food industries - why do public health practitioners view them so differently? Front Public Health. 2016;4:64.

38. Sula-Raxhimi E, Butzbach C, Brousselle A. Planetary health: countering commercial and corporate power. Lancet Planet Health. 2019;3(1):e12-e3.

39. Thorn M. Addressing power and politics through action on the commercial determinants of health. Health Promot J Austr. 2018;29(3):225-7.

40. Thurley G. Explaining the links between Commercial Determinants of Health and Chronic Diseases: European Public Health Alliance; 2017. https://epha. org/explaining-the-links-between-commercial-determinants-of-health-andchronic-diseases/. Accessed 29 Mar 2019.

41. United Nations Department of Economic and Social Affairs, United Nations Industrial Development Organization. Report of the expert meeting in preparation for HLPF 2017 on Readying institutions and policies for integrated approaches to implementation of the 2030 Agenda. Vienna: United Nations Department of Economic and Social Affairs, United Nations Industrial Development Organization; 2016.

42. West R, Marteau T. Commentary on casswell (2013): the commercial determinants of health. Addiction. 2013;108(4):686-7.

43. Wiist WH. Public health and the anticorporate movement: rationale and recommendations. Am J Public Health. 2006;96(8):1370-5.

44. World Health Organization Western Pacific Region. 2. Convening to overcome commercial determinants of health Report of the Regional Director. In: The work of WHO in the Western Pacific Region 1 July 2016-30 June 2017. Manila: World Health Organization; 2017.

45. World Health Organization Regional Office for Europe, editor Thematic paper 3: Good governance for the health and well-being of all children and adolescents. Paper presented at: Working together for better health and well-being: Promoting intersectoral and interagency action for health and well-being in the WHO European Region; 7-8 December 2016; Paris: World Health Organization; 2016.

46. Higgins JPT, Green S, editors. Cochrane handbook for systematic reviews of in terventions. Chichester: Wiley-Blackwell; 2008.

47. Tong A, Sainsbury P, Craig J. Consolidated criteria for reporting qualitative research (COREQ): a 32-item checklist for interviews and focus groups. Int J Qual Health Care. 2007:19(6):349-57.

48. Baum FE, Anaf JM. Transnational corporations and health: a research agenda. Int J Health Serv. 2015;45(2):353-62.

49. Delobelle P, Sanders D, Puoane T, Freudenberg N. Reducing the role of the food, tobacco, and alcohol Industries in noncommunicable disease risk in South Africa. Health Educ Behav. 2015;43:70S-81S.

50. Mialon M, Swinburn B, Sacks G. A proposed approach to systematically identify and monitor the corporate political activity of the food industry with respect to public health using publicly available information. Obes Rev. 2015;16(7):519-30.

51. Koivusalo M. Policy space for health and trade and investment agreements. Health Promot Internation. 2014:29:i29-47.

52. McNamara C, Labonté R. Trade, labour markets and health: a prospective policy analysis of the trans-Pacific partnership. Int J Health Serv. 2017;47(2): 277-97.

53. Baum FE, Sanders DM. Ottawa 25 years on: A more radical agenda for health equity is still required. Health Promot Internation. 2011;26(Suppl 2): ii253-ii7.

54. Bornstein SR, Ehrhart-Bornstein M, Wong ML, Licinlo J. Is the worldwide epidemic of obesity a communicable feature of globalization? Exp Clin Endocrinol Diabetes. 2008;116(Suppl 1):S30-S2. 
55. De Vogli R, Renzetti N. The potential impact of the transatlantic trade and investment partnership (TTIP) on public health. Epidemiol Prev. 2016;40(2): 95-102.

56. Watz V. Corporate consumption complex and the need for a new public health agenda. Stockholm: IOGT International; 2016. Available from: https:// iogt.org/blog/2016/11/02/corporate-consumption-complex-need-newpublic-health-agenda/. Accessed 29 Mar 2019.

57. Adams PJ, Raeburn J, de Silva K. A question of balance: prioritizing public health responses to harm from gambling. Addiction. 2009;104(5):688-91.

\section{Publisher's Note}

Springer Nature remains neutral with regard to jurisdictional claims in published maps and institutional affiliations.

Ready to submit your research? Choose BMC and benefit from:

- fast, convenient online submission

- thorough peer review by experienced researchers in your field

- rapid publication on acceptance

- support for research data, including large and complex data types

- gold Open Access which fosters wider collaboration and increased citations

- maximum visibility for your research: over $100 \mathrm{M}$ website views per year

At $\mathrm{BMC}$, research is always in progress.

Learn more biomedcentral.com/submissions 